\title{
DIVERGÊNCIA GENÉTICA ENTRE GENÓTIPOS DE ALFACE POR MEIO DE MARCADORES AFLP ( $\left.{ }^{1}\right)$
}

\author{
CRISTINA SOARES DE SOUSA $\left({ }^{2,3}\right)$; ANA MARIA BONETTI $\left({ }^{2}\right)$; LUIZ RICARDO GOULART FILHO $\left({ }^{2}\right)$; \\ JANE RODRIGUES DE ASSIS MACHADO $\left({ }^{2}\right) ;$ LUCIANA NOGUEIRA LONDE $\left({ }^{2}\right)$; MILLA ALVES BAFFI $\left({ }^{2}\right)$; \\ RENATO GRACILIANO RAMOS $\left({ }^{2}\right)$; CARLOS UEIRA VIEIRA $\left({ }^{2}\right)$; WARWICK ESTEVAM KERR $\left({ }^{2 *}\right)$
}

\begin{abstract}
RESUMO
Considerando a restrita diversidade de espécies disponíveis para nutrir a carência de vitaminas no Brasil, Kerr e colaboradores, desde 1981, vêm desenvolvendo pesquisas para melhoramento genético de hortaliças ricas em vitamina A. Dentre elas, obtiveram uma cultivar de alface, denominada Uberlândia 10.000 com 10.200 UI de vitamina A em 100 gramas de folha fresca. Este trabalho objetivou comparar o grau de divergência genética entre a cultivar Uberlândia 10.000 e seus parentais para avaliar a eficiência da seleção utilizada, por meio da técnica AFLP. Foram utilizados os seguintes genótipos de alface: Maioba, Salad Bowl-Mimosa, Moreninha-de-Uberlândia, Vitória de Santo Antão, Uberlândia 10.000 lisa 8. ${ }^{a}$ e 9. ${ }^{a}$ geração e Uberlândia 10.000 crespa 8. ${ }^{a}$ e 9. a geração. A técnica AFLP foi eficiente para identificar genótipos muito próximos e para estudos de progênies em alface. O primer PR15 permitiu a separação da forma lisa e crespa com $1,8 \%$ de divergência genética e a oitava da nona geração com apenas $0,71 \%$. Com o estudo da filogenia da cultivar pode-se observar que o programa de melhoramento foi desenvolvido com sucesso, pois a cultivar obtida Uberlândia 10.000 possui alto teor de vitamina A e $92 \%$ de similaridade com o parental Vitória de Santo Antão. O primer PR11 conseguiu identificar polimorfismo entre cultivares de alta e baixa resistência à septoriose, sugerindo a possibilidade destas bandas estarem relacionadas à resistência.
\end{abstract}

Palavras-chave: divergência genética, AFLP, alface.

\section{ABSTRACT \\ GENETICS DIVERGENCE AMONG LETTUCE GENOTYPES BY AFLP MARKERS}

Considering the restricted diversity of species available to counteract vitamin deficiencies in Brazil, Kerr and coworkers have been engaged since 1981, in developing genetic improved garden vegetables rich in vitamin A. One of these vegetables is the lettuce cultivar Uberlândia 10,000, which contains 10,200 UI of vitamin A per 100 grams of fresh leaves. This study compares the genetic diversity between Uberlândia 10,000 and its parental, evaluating selection efficiency through the AFLP technique. The following lettuce genotypes were used for this comparison: Maioba, Salad Bowl-Mimosa, Moreninha-de-Uberlândia, Vitória de Santo Antão, smooth 8th and 9th generation Uberlândia 10,000, and crinkly 8th and 9th generation Uberlândia 10,000 cultivars. The AFLP technique was effective for identifying very close genotypes and for studying lettuce progenies. The primer PR15 enabled the separation of smooth and crinkly types down to $1.8 \%$ of genetic diversity and the 8 th and 9 th generations down to only $0.71 \%$ of diversity. Phylogenetic study of the cultivar confirmed the success of the breeding program, with the Uberlândia 10,000 cultivar revealing high vitamin A content and $92 \%$ of similarity with the parental Vitória de Santo Antão. The primer PR11 allowed the identification of polymorphism between cultivars with high and low resistance to septoriosis, suggesting that these bands may be resistance-related.

Key words: genetic divergence, AFLP, lettuce.

$\left({ }^{1}\right)$ Recebido para publicação em 31 de agosto de 2005 e aceito em 31 de agosto de 2006.

$\left({ }^{2}\right)$ Instituto de Genética e Bioquímica-Universidade Federal de Uberlândia-UFU, Rua Acre, bloco 2E, Campus Umuarama, 38400-902 Uberlândia (MG). E-mail: cristsoares@hotmail.com; warwich@umuarama.ufu.br (* Autor correspondente).

$\left({ }^{3}\right)$ Bolsista CAPES. 


\section{INTRODUÇÃO}

Após várias décadas de adaptação, as hortaliças representam hoje uma importante fonte de alimento para os brasileiros, destacando sua relação com saúde e longevidade, pois fornece vitaminas necessárias ao bom funcionamento do organismo (Costa, 2000).

A alface (Lactuca sativa L.) pertence ao grupo das hortaliças folhosas mais populares, dentre as quais se destaca como uma das que tem maior importância econômica. Sua inflorescência possui de 10 a 25 flores ou floretes e é formada por uma panícula contendo vários botões florais denominados capítulos. Cada florete tem uma única pétala amarela, envolvida por brácteas imbricadas que vão formar o invólucro. O ovário é unilocular contendo um único óvulo. À medida que o estilete se alonga e atravessa o tubo formado pelos estames, ocorre a polinização e ao mesmo tempo a antese. Este processo se dá pela manhã, garantindo a autofecundação e a autogamia por meio da cleistogamia (RYDER, 1986).

A alface possui vitaminas A, B1, B2, e C, além de sais de cálcio e ferro. PRANCE (1986) não a considera uma hortaliça de destaque como fonte de vitaminas e sais minerais; Balbach (1995), porém, cita que em 100 gramas de alface, com coloração de folha verdeescura, pode haver 4.500 unidades internacionais (U.I.) de vitamina A. Quanto mais escuro o verde, maior a quantidade de vitamina A.

A carência dessa vitamina em animais causa falta de adaptação ao escuro, que pode progredir até a cegueira noturna total (nictalopia), retardamento no crescimento, redução da resistência a infecções, principalmente a resfriados e infecções dos sínus (sinusite), conforme IsLABÃo (1997).

Preocupados com a carência vitamínica no Brasil e em especial no Nordeste, Kerr e colaboradores decidiram produzir uma cultivar de alface com alto teor de vitamina A. O resultado foi a obtenção da cultivar Uberlândia 10.000 As linhagens foram selecionadas baseando-se em caracteres morfológicos, como por exemplo coloração das folhas, resistência ao pendoamento precoce, sabor doce e adaptação a variações no $\mathrm{pH}$ de 4 a 8 .

A tendência atual do melhoramento genético de plantas é a integração das técnicas clássicas com os avanços da biotecnologia, levando-se em consideração as vantagens e limitações de cada uma delas. Neste contexto, a tecnologia de marcadores moleculares pode contribuir significativamente para o conhecimento básico da cultura e do caráter estudado, e também para a geração e desenvolvimento de produtos melhorados (Ferreira e Grattapaglia, 1998).
Entre as várias técnicas moleculares disponíveis atualmente, a técnica AFLP (Vos et al., 1995) tem-se mostrado eficiente para análise de diferenças entre indivíduos geneticamente distintos. HILL et al. (1996) demonstram que AFLPs são marcadores úteis para estudar o parentesco entre espécies de alface. Essa técnica alia as características de duas técnicas, polimorfismo gerado por enzimas de restrição (RFLP-Restriction Fragment Lenght Polymorphism) e a amplificação seletiva pelo uso de primers com alguns nucleotídios aleatórios na extremidade 3' (RAPD-Random Amplified Polymorphic DNA) (Ferreira e Grattapaglia, 1998).

Esse trabalho objetivou comparar o grau de divergência genética entre a cultivar Uberlândia 10.000 e seus parentais para avaliar, a eficiência da seleção utilizada, por meio da técnica AFLP.

\section{MATERIAL E MÉTODOS}

A cultivar Uberlândia 10.000 originou-se de uma série de cruzamentos e seleções descritos a seguir. Os parentais utilizados nos primeiros cruzamentos foram Maioba e Salad Bowl-Mimosa, e do cruzamento entre esses dois parentais obteve-se a cultivar Moreninha-de-Uberlândia que, apesar de alto teor de vitamina A, possuía características inadequadas às exigências do consumidor. Essa cultivar foi cruzada com outra variedade comercial de características apreciadas pelo consumidor (Vitória de Santo Antão). Desse cruzamento resultou finalmente a cultivar Uberlândia 10.000 (Tabela 1).

Para análise de similaridade, foram utilizadas gerações avançadas $\left(8 .^{a}\right.$ e $\left.9 .^{a}\right)$ nas formas lisa e crespa da cultivar Uberlândia 10.000, e todas as cultivares que participaram na construção do seu genoma (Maioba, Salad Bowl-Mimosa, Moreninha-deUberlândia e Vitória de Santo Antão).

A extração de DNA das sementes das cultivares estudadas foi feita por Pereira e Kerr (2001) e o DNA quantificado em espectrofotômetro por leitura de absorbância $(260 \mathrm{~nm})$. Para a análise genética, foi utilizada uma mistura de DNA de 20 plantas de cada cultivar.

Para o preparo das reações utilizou-se o Kit AFLPTM Analysis System I (GIBCO BRL) e o Kit AFLP Starter Primer Kit (GIBCO BRL) seguindo as instruções do fabricante.

Para a restrição, utilizou-se 300 ng de DNA, 5 ?1 de tampão de reação, 2 ?1 da solução contendo as enzimas EcoRI/MseI e água destilada, completando para o volume final de 25 ?1. As reações 
enzimáticas foram processadas a $37^{\circ} \mathrm{C}$ por 2 horas e a inativação das enzimas a $70{ }^{\circ} \mathrm{C}$ por 15 minutos. Em seguida, foi feita a ligação dos adaptadores, adicionando ao DNA digerido da etapa anterior, 24 ?1 de solução de adaptadores e 1 ?1 de T4 ligase. A reação de ligação dos adaptadores aos fragmentos de restrição ocorreu a $20^{\circ} \mathrm{C}$ por 2 horas. Os adaptadores utilizados são descritos a seguir:

\section{Adaptador EcoR I foward} CTCGTAGACTGCGTACC-3'),

Adaptador EcoR I reverso AATTGGTACGCAGTCTAC-3'),

Adaptador Mse I foward GACGATGAGTCCTGAG-3'),

\section{Adaptador Mse I reverso TACTCAGGACTCAT-3').}

Depois da ligação dos adaptadores, fez-se a diluição da reação na proporção de 1:10 para ser utilizada na pré-amplificação, na qual $20 \mu \mathrm{L}$ de mix de primer (EcoR I: 5'-GACTGCGTACCAATCA-3' e Mse I: 5-GATGAGTCCTGAGTAAC-3'), 1U de Taq polimerase, 2,5 $\mu \mathrm{L}$ de tampão com $\mathrm{MgCl} 2,2,5 \mu \mathrm{L}$ do DNA diluído em TE com adaptador foram utilizados. A reação de PCR consistiu de 20 ciclos: desnaturação do DNA a $94{ }^{\circ} \mathrm{C}$ por 30 segundos, anelamento dos primers: $50^{\circ} \mathrm{C}$ por 1 minuto e extensão pela Taq polimerase: $72{ }^{\circ} \mathrm{C}$ por 1 minuto. A reação de préamplificação foi diluída na proporção de 1:50. Na amplificação seletiva, utilizaram-se $5 \mu \mathrm{L}$ de DNA préamplificado diluído, 5 ?L de um par de primer, $1 \mathrm{U}$ de Taq polimerase e tampão com MgCL2. A reação de PCR foi dividida em três etapas. A primeira constou de seis ciclos, em que a desnaturação ocorreu a $94{ }^{\circ} \mathrm{C}$ por 30 segundos, anelamento dos primers a $65{ }^{\circ} \mathrm{C}$ por 30 segundos e a extensão a 72 ${ }^{\circ} \mathrm{C}$ por 1 minuto. A segunda etapa constou de 6 ciclos de $94{ }^{\circ} \mathrm{C}$ por 30 segundos, $60{ }^{\circ} \mathrm{C}$ por 30 segundos e $72{ }^{\circ} \mathrm{C}$ por 1 minuto. A terceira etapa, com 23 ciclos de $94{ }^{\circ} \mathrm{C}$ por 30 segundos, $56^{\circ} \mathrm{C}$ por 30 segundos e $72{ }^{\circ} \mathrm{C}$ por 1 minuto.

Tabela 1. Características morfológicas das cultivares utilizadas no programa de melhoramento da cultivar Uberlândia 10.000 .

\begin{tabular}{lccccc}
\hline Cultivar & $\begin{array}{c}\text { Quantidade vitamina } \\
\text { A/100g de folha fresca }\end{array}$ & Sabor & $\begin{array}{c}\text { Formato } \\
\text { da cabeça }\end{array}$ & $\begin{array}{c}\text { Tipo } \\
\text { das folhas }\end{array}$ & $\begin{array}{c}\text { Resistência } \\
\text { à septoriose }\end{array}$ \\
\hline Maioba & 6.500 U.I. & Amargo & Aberta & $\begin{array}{c}\text { Medianamente } \\
\text { crespa }\end{array}$ & Suscetível \\
Salad Bowl- Mimosa & 2.420 U.I. & Pouco amargo & Aberta & Lisa & Resistência alta \\
Moreninha de Uberlândia & 8.000 U.I. & Amargo & Formato & Lisa & Resistência alta \\
Vitória de Santo Antão & 3.500 U.I. & Adocicado & Aberta & Lisa & Suscetível \\
Uberlândia 10.000 & 10.121 U.I. & Levemente adocicado & Aberta & Crespa e Lisa & Su
\end{tabular}

Fonte: (KERR et al., 1990) e (ALMEIDA, 1991).

A avaliação da qualidade do DNA foi feita em gel de agarose $0,8 \%$. Uma vez quantificada e avaliada, a amostra foi diluída em TE (10 mM TrisHCL e 1 mM EDTA pH 8,0) para a concentração de trabalho $100 \mathrm{ng} / \mu \mathrm{L}$, a qual foi mantida em freezer a $-20^{\circ} \mathrm{C}$.

A visualização das bandas foi feita em gel de poliacrilamida $8 \%$ desnaturante, 19:1, corado com $0,012 \mathrm{M}$ nitrato de prata e revelado com 0,28 M carbonato de sódio anidro segundo protocolo de (BASAN et al., 1991). O tempo de corrida das amostras foi de 7 horas, a uma voltagem de 500 $\mathrm{v}$, em tampão TBE 1X. Foi acrescentada às amostras metade do volume final $(20 \mu \mathrm{L})$ de "Stop Buffer" (Xyleno cyanol, azul de Bromofenol, EDTA $10 \mathrm{Mm}$ e formamida). As amostras foram desnaturadas a $90^{\circ} \mathrm{C}$ por 3 minutos.

Foram testadas 18 combinações de primers e analisadas 1.160 bandas polimórficas e 332 monomórficas (Tabela 2).
Foi montada uma matriz binária de acordo com presença (1) e ausência (0) de bandas reproduzíveis e mais intensas.

A matriz gerada pelo programa STATISTICA 4,5A (1993) foi usada para o cálculo das distâncias genéticas e análise de agrupamento. Calcularam-se as distâncias genéticas pelo método de Porcentagem de Desacordo, conforme a fórmula:

\section{$\mathrm{N}^{\prime} \mathrm{AB} / \mathrm{NT}$,}

Sendo: N'AB - o número total de bandas polimórficas entre os genótipos comparados e NT - o número total de bandas.

A análise de grupos foi feita pelo método nãoponderado de agrupamento aos pares, utilizando médias aritméticas (UPGMA - "Unweighted pair-group method using arithmetic average"), o qual agrupa indivíduos de acordo com a similaridade. Os indivíduos mais similares foram agrupados inicialmente e, assim, sucessivamente, até os indivíduos ou grupos mais distantes. 
Tabela 2. Relação dos primers utilizados e número de bandas polimórficas e monomórficas utilizadas para análise

\begin{tabular}{|c|c|c|}
\hline \multirow[b]{2}{*}{ PR ( Primers) } & \multicolumn{2}{|c|}{ Bandas } \\
\hline & Polimórficas analisadas & $\begin{array}{c}\text { Monomórficas } \\
\text { analisadas }\end{array}$ \\
\hline PR1 (E-AGG/M-CTA) & 64 & 24 \\
\hline PR2 (E-5'-GACTGCGTACCAATCAGC-3'/M-5GATGAGTCCTGAGTAACTG-3') & 56 & 8 \\
\hline PR3 (E-5'-GACTGCGTACCAATCACA-3'/M-5-GATGAGTCCTGAGTAACAG-3') & 56 & 16 \\
\hline PR4 (E-5'-GACTGCGTACCAATCAAC-3'/M-5-GATGAGTCCTGAGTAACAA-3') & 24 & 24 \\
\hline PR5 (E-5'-GACTGCGTACCAATCAAG-3'/M-5-GATGAGTCCTGAGTAACAG-3') & 48 & 8 \\
\hline PR6(E-5-GATGAGTCCTGAGTAACAG-3'/M-5-GATGAGTCCTGAGTAACAT-3') & 40 & 84 \\
\hline PR7 (E-5'-GACTGCGTACCAATCAGC-3'/M-5-GATGAGTCCTGAGTAACAA-3') & 80 & 0 \\
\hline PR8 (E-5'-GACTGCGTACCAATCACA-3'/M-5-GATGAGTCCTGAGTAACAC-3') & 48 & 8 \\
\hline PR9 (E-5'-GACTGCGTACCAATCACC-3'/M-5-GATGAGTCCTGAGTAACTG-3') & 88 & 16 \\
\hline PR10 (E-5'-GACTGCGTACCAATCACG-3'/M-5-GATGAGTCCTGAGTAACAG-3') & 120 & 24 \\
\hline PR11(E-5'-GACTGCGTACCAATCAGC-3'/M-5-GATGAGTCCTGAGTAACAT-3') & 104 & 8 \\
\hline PR12 (E-5'-GACTGCGTACCAATCACG-3'/M-5-GATGAGTCCTGAGTAACAC-3') & 72 & 8 \\
\hline PR13 (E-5'-GACTGCGTACCAATCACT-3'/M-5-GATGAGTCCTGAGTAACAT-3') & 40 & 8 \\
\hline PR14 (E-5'-GACTGCGTACCAATCACT-3'/M-5-GATGAGTCCTGAGTAACTT-3') & 64 & 16 \\
\hline PR15 (E-5'-GACTGCGTACCAATCACA-3'/M-5-GATGAGTCCTGAGTAACTT-3') & 56 & 0 \\
\hline PR16 (E-5'-GACTGCGTACCAATCAGC-3'/M-5-GATGAGTCCTGAGTAACTC-3') & 48 & 32 \\
\hline PR17(E-5'-GACTGCGTACCAATCAAG-3'/M-5-GATGAGTCCTGAGTAACAA3') & 72 & 16 \\
\hline PR18 (E-5'-GACTGCGTACCAATCACC-3'/M-5-GATGAGTCCTGAGTAACAG-3') & 80 & 32 \\
\hline Total & 1.160 & 332 \\
\hline
\end{tabular}

\section{RESULTADOS E DISCUSSÃO}

Quando Kerr e colaboradores cruzaram 'Moreninha-de-Uberlândia' (parental masculino) com a 'Vitória de Santo Antão' (parental feminino), o objetivo era obter uma cultivar com alto teor de vitamina A, semelhante ao parental masculino e com outras características de 'Vitória de Santo Antão' tais como sabor adocicado, folhas soltas e comportamento de cultivar de verão, podendo ser produzida em Uberlândia e outras cidades mais quentes, sem problemas de pendoamento precoce. A seleção foi feita com base em plantas de coloração verde-escura e análise química das folhas para determinação do teor de vitamina $A$ e características fenotípicas mais próximas à 'Vitória de Santo Antão'. Neste trabalho, a técnica AFLP foi adequada para estudos filogenéticos, confirmando o sucesso do programa de melhoramento, visto que a cultivar obtida, denominada 'Uberlândia $10.000^{\prime}$ possui alto teor de vitamina A e $92 \%$ de similaridade com o parental Vitória de Santo Antão (Figura 1). Observa-se nessa mesma figura que a divergência genética entre os parentais foi de $51 \%$. A caracterização molecular de genótipos tem-se tornado uma ferramenta de grande importância para os programas de melhoramento genético, uma vez que cruzamentos entre indivíduos com maior diversidade genética podem contribuir para a ampliação da variabilidade em populações segregantes (MESSMER et al., 1993), possibilitando maior ganho genético.

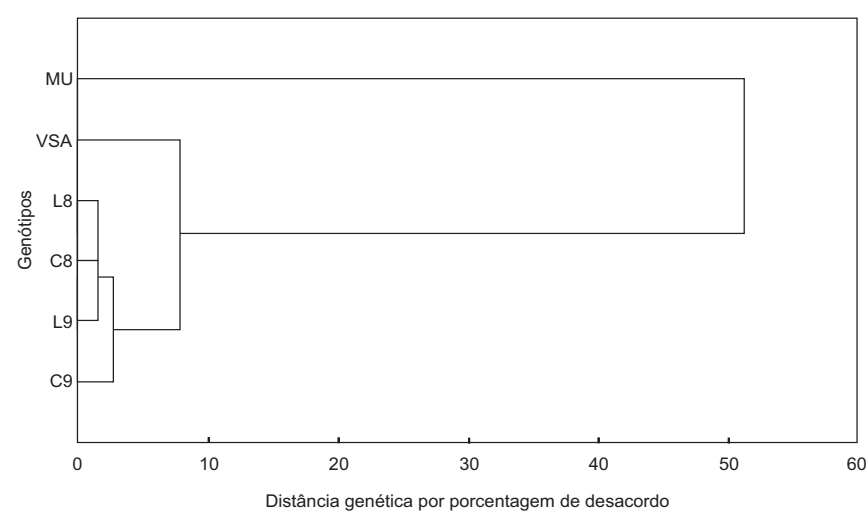

Figura 1. Dendrograma representativo da distância genética por porcentagem de desacordo e agrupamento pelo método de UPGMA entre 6 genótipos utilizando 18 primers, citados anteriormente. MU: 'Moreninha-deUberlândia'; VSA: 'Vitória de Santo Antão'; L8: 'Uberlândia 10.000 lisa 8. ' geração'; C8: 'Uberlândia 10.000 crespa $8 .^{\text {a }}$ geração'; L9: 'Uberlândia 10.000 lisa 8. ' geração'; C9: 'Uberlândia 10.000 crespa 9. ' geração'.

Como se observa na figura 2, a combinação dos primers E-ACA e M-CTT permitiu a separação entre as formas lisa e crespa com 1,8\% de divergência genética e entre a oitava e nona gerações com apenas $0,71 \%$. Esse valor próximo a zero observado entre essas duas gerações avançadas, confirma a hipótese de que nessas gerações praticamente já não há mais segregação, estando as plantas com alto nível de homozigose. 


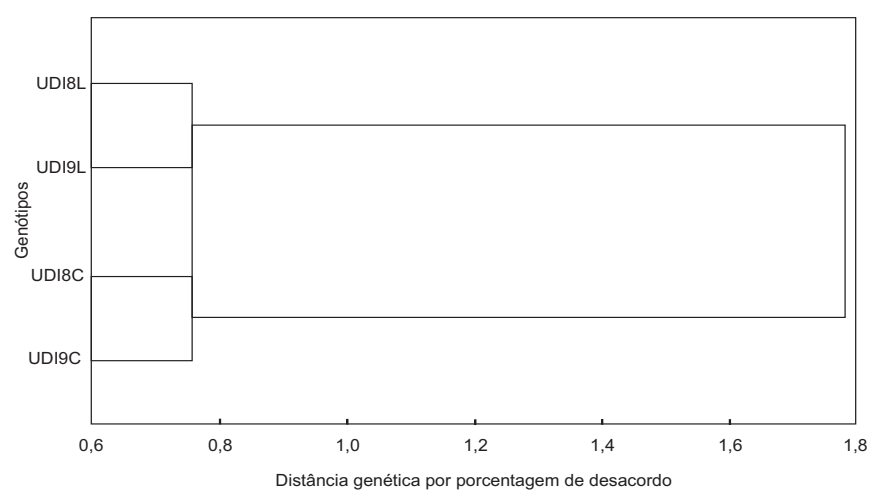

Figura 2. Dendrograma representativo da distância genética por porcentagem de desacordo e agrupamento pelo método de UPGMA entre 4 genótipos utilizando a combinação de primers E-ACA e M-CTT. UDI8L: 'Uberlândia 10.000 lisa 8. a geração'; UDI8C: 'Uberlândia 10.000 crespa $8 .^{\text {a }}$ geração'; UDI9L: 'Uberlândia 10.000 lisa $8 .^{\text {a }}$ geração'; UDI9C: 'Uberlândia 10.000 crespa 9. geração'.

Sousa et al. (2003) avaliaram diferentes cultivares de alface quanto a resistência à septoriose e observaram que a cultivar Maioba foi a mais suscetível, não diferindo significativamente da cultivar Uberlândia 10.000, enquanto a Vitória de Santo-Antão possía maior resistência em relação às demais, não diferindo significativamente da SaladBowl-Mimosa.

No estudo da divergência genética entre a cultivar Uberlândia 10.000 e seus parentais (pais e avós) utilizando 18 combinações de primers, observou-se grande similaridade genética $(87 \%)$ dela com a avó Maioba e Vitória de Santo Antão (Figura $3)$, podendo sugerir que a característica de susceptibilidade ou resistência à septoriose não tem relação alguma com a divergência genética.

A combinação dos primers E-AGC e M-CAT conseguiu identificar polimorfismo entre cultivares de alta e baixa resistência a septoriose, segundo citação da literatura (Sousa et al., 2003), sugerindo a possibilidade desses fragmentos estarem relacionadas à resistência a essa doença. Porém, para confirmação dessa hipótese, faz-se necessário o seqüenciamento desses fragmentos e posterior comparação no banco de dados para verificar sua participação em alguma via metabólica relacionada à resistência a doenças causadas por fungos. Esse resultado pode tornar-se útil em um programa de melhoramento assistido por marcadores moleculares, visando à transferência da característica de resistência entre cultivares divergentes de alface.

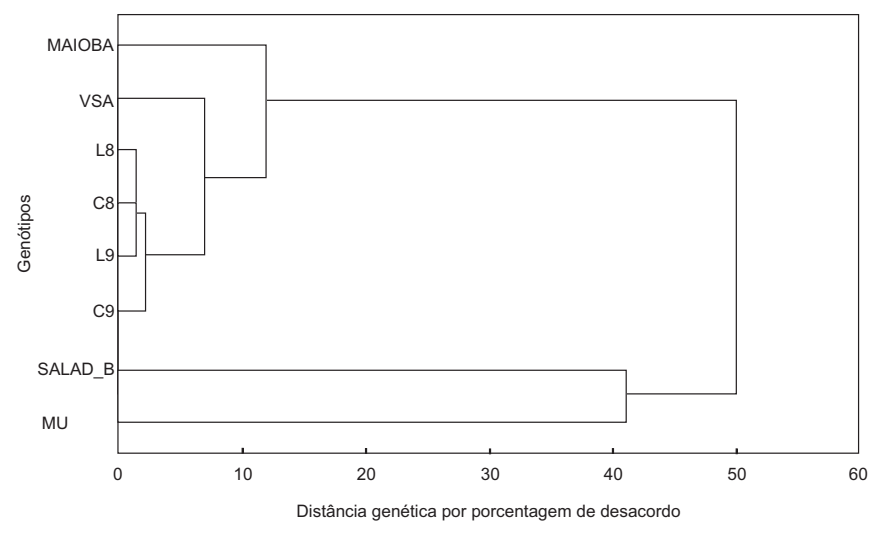

Figura 3. Dendrograma representativo da distância genética por porcentagem de desacordo e agrupamento pelo método de UPGMA entre 4 genótipos utilizando 18 primers. L8: 'Uberlândia 10.000 lisa $8 .^{\text {a }}$ geração'; C8: 'Uberlândia 10.000 crespa $8 .^{\text {a }}$ geração'; L9: 'Uberlândia 10.000 lisa 8. ' geração'; C9: 'Uberlândia 10.000 crespa 9. ${ }^{\text {a }}$ geração'; VSA: 'Vitória de Santo Antão'; MU: 'Moreninhade-Uberlândia', Salad-B: Salad Bowl- Mimosa.

\section{CONCLUSÕES}

1. A técnica foi adequada na avaliação de diversidade genética em alface.

2. Pela similaridade entre Uberlândia 10.000 e Vitória de Santo Antão (92\%) verifica-se que a seleção foi eficiente.

\section{REFERÊNCIAS}

BALBACH, A. As hortaliças na medicina doméstica. 26.Ed. São Paulo: Vida Plena, 1995. 407p.

BASAN, B. J.; CAETANO-ANOLES, G.; GRESSHOFF, P. $M$. Fast and sensitive silver staining of DNA in polyacrylamide gels. Analytic Biochemical, New York, v.196, p.80-83, 1991.

COSTA, C. P da. Olericultura brasileira: passado, presente e futuro. Horticultura Brasileira, Brasília, v. 18, p. 7-11, Jul., 2000. (Suplemento. Conferências)

FERREIRA, M. E.; GRATTAPAGLIA, D. Introdução ao uso de marcadores moleculares em análise genética. 3 Ed. Brasília: EMBRAPA-CENARGEM, 1998. 220p.

HILL, M.; WITSENBOER, H.; ZABEAU, M.; KESSELI, R.; VOS, P.; MICHELMORE, R. PCR-based fingerprinting using AFLPs as a tool for studying genetic relationship in Lactuca sp. Theoretical Applied Genetic, Berlin, v.93, p.1202-1210, 1996. 
ISLABÃO, N. Vitaminas: seu metabolismo no homem e nos animais domésticos. 2 ed., São Paulo: Nobel, 1997. p.29-48.

MESSMER, M.M; MELCHINGER, A. E.; HERMANN, R.R.; BOPPERNMAIER, J. Relationships among early european maize inbreeds: I. Comparasion of pedigree and RFLP data. Crop Science, Madison, v.33, p.944-950, 1993.

PEREIRA,C.D.; KERR, W.E. Divergência Genética entre Doze Genótipos de Abacaxizeiro (Ananás comosus L. Merril) estimada por Análise de Marcadores RAPD. Revista Brasileira de Fruticultura, Jaboticabal, v.23, p.335-338 , 2001.

PRANCE, G.T. Manual de Botânica Econômica do Maranhão. Maranhão: Gráfica Universitária, 1986. 254p.
RYDER, E.J. Lettuce breeding. In: Breeding Vegetables Crops. Westport, Connecticut: AVI Publishing, p.433-474. 1986.

SOUSA, C.S.; KERR, W.E.;SANTOS, M.R.; ARRUDA, A.S.;SPINI V.B.M.G.; JULIATTI, F.C.; TAKATSU,A. Mancha de Septoria da alface: isolamento, inoculação e avaliação de cultivares em condições de campo e casa de vegetação. Fitopatologia Brasileira, Brasília, v.28, n.5, p.555-558, 2003.

VOS, P.; HOGERS, R. ; BLEEKER, M.; REIJANS, M.; VAN DE LEE, T.; HORNES, M; FRIJTERS, A.; POT, J.; JPELEMAN; KUIPER, M.; ZABEAU, M. AFLP: A new technique for DNA fingerprinting. Nucleic Acids Research, London, v.23, p. 44074414, 1995. 